\title{
Relativizing Universality: Sociological Reactions to Liberal Universalism
}

\begin{abstract}
This paper offers an appraisal of the relationship between sociology and philosophy grounded in a critique of the former discipline's failure to contend with the dominance of neoliberalism in the run up to the financial crisis. In the first instance, it considers the prevailing philosophical ethos after the end of the Cold War and what Francis Fukuyama (1992) called the 'End of History'. It observes the emergence of an increasingly unchallenged political monad around the conjoined principles of liberal democracy and neoliberal economics and its ascendance to the status of socio-historical universality despite becoming increasingly problematic. The second half of the essay then carries this politicalphilosophical analysis into an exploration of contemporary sociology and its approach to the intellectual critique of dominant ideas and structures. It proposes that an emergent strain of philosophical relativism has inadvertently moved us away from some of the critical responsibilities of the traditional intellectual and eroded our capacity to offer practical alternatives to overwhelmingly neoliberal governance. The article ends on the hopeful note that a slight change in tack might push us toward reclaiming responsibilities and revitalising the debate on social transformation.
\end{abstract}

\section{Key Words}

Neoliberalism, Relativism, Universalism, Capitalism, Cultural Turn

\section{Introduction}

On Sunday 12 October 2008, Alistair Darling, then Chancellor of the Exchequer, left the Washington headquarters of the International Monetary Fund (IMF) and boarded a flight back to London. Darling's experience of his otherwise unremarkable business class flight, however, was marred by external turbulences of which few of his fellow passengers would have been aware. The City of London, the financial bedrock of the British economy, was in trouble and an implosion to rival the 1930s was well and truly on the cards. Unless a plan could be finalized before markets reopened the following morning the public might have headed out to work to find cash points inoperable, credit/debit cards unusable and the whole economy facing a terminal collapse of its monetary base.

Hours from disaster, the highest echelons of government convened in a bid to prevent capitalism reaching crisis point. Less than a year after Northern Rock's nationalization, the rest of the financial sector was staring down the same surfeit of 'bad debt'. Once again, the state would have to step in. To do nothing risked wholesale economic collapse and everything that implies - national bankruptcy, mass social unrest, economic shockwaves pulsating over Europe and the rest of the world and perhaps even irreparable damage to the public standing of 
neoliberal capitalism itself. The following morning, only hours after arriving home, the Chancellor stood grave and haggard beside the Prime Minister. With all the resigned solemnity of a declaration of war the British state declared its intention to do everything in its power to buttress financial capitalism in the name of 'businesses, working families and home-owners' (BBC News, 2008).

For decades prior to this financial impasse we had been told that business, including international finance, should be given as much freedom as possible and that the only way to ensure future prosperity was to legislate for a libertarian, light touch approach to economic regulation (Chang, 2010). This represented the fundamental neoliberal economic principles that politicians of all parties had stood for since 1979. For three decades our political leaders have stood for 'the freedom of private firms to seek profit in any way they could' (Wallerstein, 2011: 6 ) and the undesirability of state regulation unless it aids the functioning of free markets (Harvey, 2005). This 'economic liberalism' was, and remains, the linchpin of British politics: an unimpeachable truth, without question the best way to organise an economy, a system that seemed somehow connected to all the utopian imaginings of classical liberalism; the rational economic actor, unencumbered by state interference, driving the economy forward with his/her entrepreneurial dynamism and thirst for profit. In little else have we more earnest faith than concepts such as 'innovation', 'entrepreneurialism' and 'economic growth' (Deutschmann, 2001). Indeed, the political class was so convinced of the moral rectitude of economic liberalism that Francis Fukuyama (1992), along with many of his contemporaries, drew the conclusion that it represented the end point of our philosophical development. It was to be the 'end of history', the 'final form of human government'.

Ultimately, this might appear to be a conviction that 'politics', the 'art of living together and... search[ing] for the common good' (Rancière, 2005: 23), has fulfilled its promise and must now turn its hand to preserving and administering neoliberalism's high-water mark. Consequently, any sense of political bipolarity seems to have fallen away to be replaced by a political culture that sees its role extending no further than technocratic stewardship (Žižek, 2010). In this context, the purpose of this paper is twofold: first, to examine in a little more detail the political and philosophical tenor of liberal society at the 'end of history' and then to look at how recent directions in sociological theory might be related to latetwentieth century political monism.

\section{Liberal Universalism}

The starting point for this paper is a widely acknowledged development in the political outlook of much of the industrialized world since the late nineteeneighties. Slowly but surely competing discourses of political economy were replaced by the dominant, absolutely hegemonic neoliberalism at Fukuyama's 'end of history'. Progressive ideals, fundamental ideological oppositions and attempts to transform human conditions gave way to 'the end point of mankind's ideological evolution and the universalization of western liberal democracy as the final form of human government' (1992: 4). 
According to Boltanski and Chiapello (2005), capitalism has become an entirely different beast over the last few decades; seamlessly combining increasingly polarized social relations with rhetorical devices traditionally associated with various forms of progressivism (liberty, justice and fairness). Allied to this process was the willingness of much of the left to eschew traditional narratives (class struggle, collectivism and injustice) in favor of the politics of possessive individualism and private identities. 'Liberty', once associated with the struggle against overt repressive domination, has been recast as "liberation [that] is predominantly conceived as setting free the oppressed desire... to be who one wants to be, when one wants it' (Ibid. 434). This liberty to pursue hedonic desires is far less inimical to capitalism than traditional conceptions of human freedom. More than that, however, it also constitutes a fundamental redefinition of what it means to be 'free', placing much more emphasis on the many individualized opportunities afforded by neoliberal capitalism and far less on collective action and 'the common good'. In this sense, we have arguably reached a new form of capitalism which, rather than exercising power in overtly oppressive ways, 'enchant[s] its subjects with dreams (of freedom, of how your success depends on yourself, of the run of luck which is just around the corner, of unconstrained pleasures...)' (Žižek, 2009: 26) thus facilitating internalisation of the most capital-friendly socio-economic conditions and broad acquiescence to its various necessities even where we might point to a number of serious flaws.

While a more detailed discussion of neoliberal trajectories would perhaps be desirable it is sadly beyond the bounds of this paper. The crucial point to carry forward is that this 'new spirit of capitalism', otherwise known as neoliberalism, has largely succeeded in realigning much of our social outlook with the needs of unfettered capital accumulation. Traditional Protestant values such as saving and frugality, for instance, hold little profitability for an economic system based on all manner of complex financial operations (including the practice of 'securitization', which involves packaging and reselling debts on the international money markets, [see Ferguson, 2008]) and consumer culture. The rise of neoliberalism, however, was accompanied by an individualist ethos of personal solipsism in which the ubiquitous opportunity to 'buy now - pay later' kicked off the upward progression of outstanding consumer debt that very nearly finished off our economy. What is more, despite applying downward pressure to wages, widening the gap between rich and poor and relying heavily on a ready supply of easily obtained credit, neoliberalism looked inordinately successful until its fortunes took a downward turn with the beginning of the 'credit crunch'. For all intents and purposes, it appeared to usher in an era of low unemployment, steady growth, relative stability and generalized prosperity (see Elliott $\mathcal{E}$ Atkinson, 2007; Toynbee \& Walker, 2010) that further served to legitimize neoliberalism in the eyes of the general population. This apparent success contributed to the belief structure that is the subject of this essay - that neoliberalism can provide for all of our needs and that a 'single economic and political system... [is] coming into being throughout the world' (Gray, 2007: 104). Neoliberalism and utopian liberal democracy now occupy the space left by radical, progressive narratives and the possibility of a better world. 
The structure of human society at the 'end of history' appears to have become a one horse race in which all the other runners fell at early fences by not sufficiently distancing themselves from totalitarianism and revolutionary change. It seemed that to strive for radical social change was inevitably to fail - in such circumstance neoliberalism seemed the safest bet. Alain Badiou has described this as a 'conviction that to want something better is to want something worse' (2010: 1), which has significantly bolstered neoliberalism and its emergent position as the only decent, humanistic social order available to mankind. In this vein, neoliberal ideologues have often claimed that liberal economic theory 'provided a mode of seeing and a way of organizing the world that could diagnose a country's fundamental condition, frame the terms of its public debate, and propose remedies for its improvement' (Mitchell, 2007: 1) all in ways that would not conflict with the competitiveness and self-interest that they often assume innate to our species. Again according to Badiou:

\begin{abstract}
Depending on what moment we examine, the [twentieth] century appears to operate on one of two maxims: one, (operative today, for example) calls for renunciation, resignation, the lesser evil, together with moderation, the end of humanity as a spiritual force and the critique of 'grand narratives'. The other - which dominated the 'short century' between 1917 and the 1980s inherits... the will to 'break the history of the world in two', and seeks a radical commencement that would bear within it the foundations of a reconciled humanity (2007: 31 ).
\end{abstract}

This marked socio-historical shift remains absolutely crucial to understanding our current social predicament. In place of the will to split world history that made the twentieth century such an Age of Extremes (Hobsbawm, 1995), of radical political movements and myriad social innovations, recent decades have been characterized more by renunciation of revolutionary change followed by retreat toward socio-economic liberalism. We have experimented with putting ever more of the commons back into private hands, tried scaling back labor protection and removing constraints from international finance and placing great faith in (neo-)liberal economic principles that have undoubtedly proved flawed on many previous occasions (see Mackay, 1852; Galbraith, 1994; Kindleberger, 2000; Reinhart \& Rogoff, 2009). In the space of three decades we all but disavowed the gains made during the decades of the social democratic settlement after World War Two and reinstituted the preceding classical liberal order in response to nineteen-seventies economic stagnation (Frieden, 2006) and the claims made by politicians on both sides of the Atlantic that neoliberalism could deliver us safe from turbulent seas.

Neoliberalism may well be 'sufficiently productive enough to be generally accepted' (Gray, 2007: 113) and opening economic borders has undoubtedly allowed more people to participate in trade (Sorman, 2009). Yet as much as it appears 'more tolerant - unbothered about 'family values', no longer pervasively homophobic, less deeply racist and... not so fixated on issues of class' (Gray, 2007: 114) there are a host of demerits that must also be mentioned. Ours is a society that appears to be rapidly becoming more unjust, insecure and unequal (Elliot \& Atkinson, 1998; Wilkinson \& Pickett, 2009; Dorling, 2010; Hutton, 2010; Southwood, 2011), increasingly debt-ridden (Pettifor, 2006; Elliot $\&$ Atkinson, 
2007; Langley, 2009; Harvey, 2010), with a dislocated population prone to signs of stress, anxiety and depression (Lane, 2000; Schumaker, 2006; Freeman $\mathcal{E}$ Freeman, 2008). Internationally, neoliberalism appears even more suspect, implicated in similar atrocities to those often thought constitutive of progressive collectivist regimes. It has, for instance, a terrifying propensity for aiding despots and dictators when their continued power serves its interests (Johnson, 2002; Kinzer, 2003; Pilger, 2007), and a habit of interfering in foreign sovereignty for the same reasons whilst promoting an economic system prone to institutionalized instabilities and atrocities of its own (see Chomsky, 2004; Bakan, 2005; Losurdo, 2011).

Nowhere, however, is neoliberalism subjected to the same level of skepticism, apprehension and outright revulsion as more collectivist alternatives. Cambodian killing fields, the Holocaust, purges, pogroms, gulags and the Chinese Cultural Revolution are trotted out at the slightest provocation by defenders of neoliberalism while our war crimes, environmental negligence and disregard for foreign human life are acknowledged only in passing. Without getting embroiled in the interminable argument over the most murderous ideology, it should immediately be noted that the historical character of leftist progressivism appears to rest on its many failures but not its successes while neoliberalism's reputation appears to rest on a few limited successes. Yet in Britain and the United States, not to mention Continental Europe, the Social Democratic era was anything but a failure. In fact, it was a 'golden age of capitalism' in which longterm economic stability and sustained growth (Arrighi, 2010; Callinicos, 2010; Wolf, 2010) combined with dramatic social innovations that went a long way to improving everyday life. Funded by highly progressive taxation the Social Democratic state ploughed revenue into welfare programs that smoothed over some of the ingrained social inequalities generated by pre-war 'neoclassicism' (the philosophical antecedent of our 'neoliberalism') whilst improving general security and quality of life for industrial populations (Standing, 2011). Still, the failures of leftist collectivism are seen to be inevitable but those of neoliberalism are only episodic lapses, certainly nothing that should stop it getting just one more bite of the cherry. This, according to Alain Badiou, is the foundation of current political orthodoxy in the developed, liberal west:

'[W]e have here, almost unchanged, all the arguments of the American anticommunism of the 1950s: socialist [read 'radical', 'leftist' or 'progressive'] regimes are loathsome despotisms and bloody dictatorships. At the level of the state, this socialist 'totalitarianism' must be contrasted with representative democracy, which, while it is of course imperfect, is by far the least bad form of government... Because it has ended in failure all over the world, the communist hypothesis is a criminal utopia that must give way to a culture of 'human rights'... the cult of freedom (including, of course, freedom of enterprise, the freedom to own property and to grow rich that is the material guarantee of all other freedoms)' (2010: 1-2)

It is also an impasse that has affected our lives much more over the last few years as some of the veneer of success that served to legitimate neoliberal capitalism has been stripped away by internal instabilities and subsequent political attempts to shore up its foundations. Over the last few decades, however, the 
notional supremacy of liberal capital has become more than just an article of faith expressed by various economists, ideologues and politicians. Apparent success transformed emergent neoliberalism into a full-blown millenarian ideology ripe for global exportation. Gray notes that 'purged of the doubts that haunted its classical exponents, the belief in the market as a divine ordinance became a secular ideology of universal progress that in the late twentieth century was embraced by international institutions' (2007: 105). Such millenarian liberalism became the latest expression of the enlightenment faith that we are evolving toward a universal civilization. In this vein, recent decades have been dominated by confident expectation that liberal democracy will, at some point in the future, ascend to power in every corner of the globe. More importantly, the activities of western-dominated international institutions (the IMF, the World Bank, the UN and NATO, for instance) could help turn aspiration into concrete political reality and should institute policies toward such ends.

The boost given this (re-)emergent ideology by the end of the Cold War seems to have led Anglo-American leaders to the possibility that domestic success could be replicated elsewhere. It seems that 'led by [Margaret] Thatcher, western governments told the countries of the former Soviet block that if they wanted prosperity they had to import the free market' (Ibid. 117). The notion that the same policies that pulled the Anglophone economies out of the nineteenseventies stagnatory mire could be replicated in other contexts quickly became a truism of twentieth century politics. A new breed of economists, the 'Chicago boys', set about exporting liberal economics to South America, while the IMF and World Bank did their part through structural adjustment conditions requiring economic liberalization as a pre-requisite of international aid.

Many of the world's developed nations entered the twenty-first century playing host to a millenarian political order that they actively aspired to export around the globe. This core proposition of western ideological faith still seems to form a substantial part of the operating principles of international institutions despite a number of historical refutations. The fall of Soviet Communism in 1990 was taken as a sign that all states within its zone of influence would adopt westernstyle liberal democracy and the free market. However, as a consequence of attempts to install free market liberalism, post-communist Russia 'produced... a species of mafia-dominated anarcho-capitalism' (Gray, 2002: 133) that further impoverished the Russian people and perhaps pushed them toward the autocratic leadership of Vladimir Putin and Dmitry Medvedev. In much the same vein, various South American peoples continue to display a marked fondness for popular leftist regimes (such as those led by Hugo Chavez, Evo Morales and Raul Castro) after their fateful experiences with US-orchestrated liberalism during the last century. Yet, as events abroad appear to challenge the neoliberal version of history it only seems to be asserted with more vigor. The terrorist attacks on London and New York in the last decade, for instance, were not taken as signs of an increasingly frustrated world at odds with the international conduct of neoliberalism but of the necessity for a generational 'war on terror' to rescue foreign peoples from their own inadequacies.

What we have perhaps seen emerge during recent decades is a new political monad that conceives of its own existence as the triumph of human history. 
Neoliberalism has arguably become a subject of 'universal notions that do not just describe 'how things are' [in our particular socio-historical context] but serve to prescribe and insist that this is 'how things must be' [in all possible contexts and futures]' (Williams, 2011: 5). In other words, it seems to have become a new object for the enlightenment faith in historical progress - a 'universality' that appears to be 'the only game in town' (Žižek, 2000: 95). In the coming pages, I want to explore the sociological response to this growing sense of political certainty. How did sociological intellectuals react to neoliberalism's claims to represent some form of historical truth, the end point in a developmental process that was always heading this direction?

\section{Relativising the Universal}

Based on the first section of this essay we might be reminded of an observation common amongst leftist philosophers such as Fredric Jameson and Slavoj Žižek, that it is now 'easier to imagine the end of the world than the end of capitalism'. Certainly we might observe that while alternative socio-political narratives 'no longer exists as a coherent programme of government' (Cohen, 2007: 11) much of our media and scientific output consists of apocalyptic scenarios and doomladen assessments of various 'risks'. From science fiction's obsession with postapocalyptic landscapes and zombie plagues to the predictions of rising sea levels, desertification, resource wars and population crashes associated with modern climate science (see, for instance, Lovelock, 2009; Vince, 2009; Dyer, 2010), it remains difficult to escape the notion that society genuinely could come crashing down. Equally, however, we are also faced with the possibility that neoliberalism 'seamlessly occupies the horizon of the thinkable' (Fisher, 2009: 8) to such an extent that it seems certain to see us all out. Faced with such overwhelming conviction from a political order quite as problematic as millenarian neoliberalism we might be forgiven for enquiring after competing conceptions of the social good.

Of course practical alternate visions of how society should work do not spontaneously erupt from nothing but are often the product of 'intellectuals' with the time and inclination for patient analysis and deep thought. Thus we concentrate our efforts on those who might claim a measure of intellectualism. To the extent that intellectuals have been responsible for establishing an 'atmosphere of hostility to capitalism' (Schumpeter, 1942: 145) we should probably acknowledge that their relationship with seats of power has often been a little fraught. From Galileo and Marx through to the modern day, intellectuals have often stood in opposition to accepted dogmas and taken-for-granted assumptions, pursuing instead what they individually perceived to be 'the truth'. What's more, we might note that sociology, at least as much as any other social science discipline, has its roots in and perhaps owes many of its successes to various creeds of radical intellectualism. According to the late Eric Hobsbawm, for instance, the history of sociology remains inextricable from Marxism:

'From the late $19^{\text {th }}$ century on, sociology, the attempt to understand the operations of society, overlapped with both Marx and the more general aim 
of changing and not merely interpreting the world... The extraordinary expansion of higher education since the 1960s had given it [sociology] unusual prominence... and political radicalisation had made it a subject of choice for many students' (2011: 390).

More than that, however, many late-twentieth century sociologists asserted that being 'an intellectual' involves extending expertise into the political realm and applying it to the creation of a society that better fulfils the needs and requirements of its population (see Bauman, 1987; Bourdieu, 1988, for example). This function we supposedly perform by being more concerned with ultimate values (truth, justice and decency) and raising uncomfortable questions about prevailing beliefs and customs. According to Frank Furedi, 'being an intellectual implies social engagement... It involves... the assumption of social responsibility and taking a political stand' (2004: 35).

In essence, the social function of intellectualism might seem to involve holding to the possibility of solving social problems through the mutability of social structures and their governing ideas. If this is a fair description of what it means to be involved in an intellectual enterprise then it would seem to be directly inimical to any system of thought that holds existing structures to be immutable, such as that outlined above. In this context, the question crucial to our ongoing analysis is what the affect of millenarian liberalism's ideological monism might have been on such an avowedly critical enterprise determined to maintain its distance from seats of power and, ostensibly, at least, associated with various forms of radicalism (it is perhaps worth mentioning that this does not just mean those working on 'the left'. Under neoliberal universality traditional one-state conservatism may be just as 'radical' as any collectivist alternative)?

Might some disavow their earlier convictions as impractical youthful idealism and drift perceptibly toward millenarian neoliberalism? Might others cling on for dear life, holding to the radical promise despite looking increasingly out of touch? In others:

[T] he radical impulse would persist, but would be forced to migrate elsewhere. The governing assumptions of such an epoch, one imagines, would be that the system itself was unbreachable; and a great many radical positions... could be seen to flow from this gloomy presupposition. One might expect, for example, that there would be an upsurge in interest in the crevices and margins of the system - in those ambiguous, indeterminate spots where its power seems less implacable (Eagleton, 1996: 2)

Yet following from the image of the traditional, politically engaged intellectual we might also expect a profusion of wide-ranging research on the many downsides of millenarian liberalism, motivated by various ideals and commitments to the mutability of social structures. In truth, there are many examples of all of these different possibilities, be it sociology's multifaceted engagement with consumerism or a generally fairly suspicious take on the culture that has developed alongside neoliberal capitalism (see, for instance, Hall et al, 2008; MacDonald, 2009; Hall, 2012). However, such qualification must be met with the possibility that concurrent developments on the other side of the political fence might appear to favor only one of these possibilities. 
As neoliberalism began to move back toward the political mainstream, the collectivist successes of post-war social democracy (less social inequality, relative prosperity and rapid technological advancement, for example) radically altered the constituency of the democratic left. 'Hard graft in traditional factories, mines and transport industries was giving way to automation, the rise of the service industries and an increasingly feminized labor force' (Judt, 2010: 86). These transformations, further spurred by nineteen-seventies economic stagnation, gave the 'old left' a dwindling constituency less able to count on the loose collectivism of traditional working class communities. In their place came a new generation born into an era of relative prosperity and significant movements toward social justice. Where the 'old left' had accepted intrusive top-down legislation as the necessary price of social justice and economic security, the "new left' was far more at home to disenchantment with political institutions, differentiation and demands for the state to respect individualized 'rights'.

Fairly hesitantly at first, the nineteen-seventies and even more so the nineteeneighties would see the left move away from engaging an increasingly universalistic version of neoliberal capitalism by holding to competing political narratives. Instead, the left took to questioning the claims of universalism at every turn by adopting a philosophical posture that celebrated diversity and opposed universalistic values wherever they might rear their head. According to Furedi, this program drew much of its inspiration from universalizing capital 'because western capitalism presented its values as universal, the new left unthinkingly became opposed to it [universality]' (2004: 61).

What we saw emerging was a 'cultural turn' toward 'particularism, heterogeneity and difference' that grounded its interpretations of everyday life in the language of relativism and relativistic conceptions of individual behaviour. Boudon, for instance, has noted that an emergent relativism (the perspective that values and ideas have no objectivity, or, more importantly, that they are fundamentally subjective and relate only to those holding them) may be a candidate for a new 'secular religion' in which we 'tend to see all norms through 'culturalist' spectacles: each 'culture' has its own norms and values' (2004: 3). Such observations flow from the objective fact of human diversity - there are many moralities, many ways of seeing the world and of behaving within it and that these differ both between and within cultures. Yet the truly 'relativistic turn comes when you transfer these perspectives into the first-person perspective of a moral agent... and you conclude that there is no one true morality but many' (Lukes, 2008: 115).

In more sociological terms, the emergence of such a relativistic approach to social phenomena refers to 'adopting a particularistic worldview linked to the politics of identity' (Furedi, 2004: 61). This particularism might then hold to the possibility that individuals living in a universalistic neoliberal society would find their own way to resist its dominance through individualized forms of selfexpression without recourse to the realm of universalistic ideas, metanarratives and macro-processes. Hence, their perspective would be 'culturally relative' to beliefs held in isolation and would allow such individuals to hold out against a universalistic conception of the social good. In such circumstances we might see a profusion of sociological research that expressed 'enthusiasm for diversity, 
multiplicity, and the agency of consumers actively transforming their lifestyles' (Dean, 2009: 9) and the development of an 'intense sense of cynicism toward causes and ideas' (Furedi, 2004: 74) that arguably amounts to a rejection of socio-political mutability's revolutionary promise.

Perhaps unsurprisingly, given British sociology's roots in the left-of-centre discourses of the latter half of last century, much of this new philosophical orientation seems to have been adopted in one form or another. Rojek and Turner, for instance, observe that 'decorative sociology' (a tendency to focus on culture and its interpretation with a habit of reading politics into cultural activities) 'has taken root with such tenacity that it is now the most powerful tendency in critical cultural studies and cultural sociology' (2000: 639). More than anything else this appears to have involved an orientation toward social theory in which macro-interpretations of social phenomena as the result of broad processes felt across social structures are pushed to the sidelines while individualized local images of diversity are foregrounded. In other words, 'Large claims about macro-processes - modernization, secularization, rationalization are viewed by [sic] skepticism, while arguments that favor local images of postmodern society as a fragmented and diverse social reality are readily accepted' (Boudon, 2004: vi).

Most importantly, however, the over-riding assertion appears to be that no matter the claims of a singular historical universality it all comes to naught when faced with the multitudinous interpretations of individuals making their own way in a fragmented and diverse social reality. Some of the most prominent facets of modern sociology appear to flow from this relative diminution of macroprocesses in favor of a micro-sociology that studies the social world in eversmaller discreet units. On one hand, for instance, we seem to have developed a marked fondness for methodological complexity, empiricism and claims to objectivity that mirror aspects of the natural sciences, while on the other we have the emergence of concepts such as 'identity politics' (also known as 'life' or 'lifestyle' politics) that might seem to privilege the individual over macroprocesses. While we are sadly lacking the space for full analysis of such expressions of this new philosophical orientation the latter is perhaps worth a little more detail.

Identity politics 'concerns political issues, which flow from processes of selfactualization in post-traditional contexts, where globalizing influences intrude deeply into the reflexive project of the self, and conversely where processes of self-realization influence global strategies' (Giddens, 1991: 214). These 'life politics' provide a basis on which to claim that individual behaviour in almost any area of social life can be 'political', harboring each individual citizens' approval and/or disapproval, consent and/or rejection, of large-scale social structures and the powers that be. In other words, the Foucauldian determination that there is no such thing as 'universal truth', that metanarratives should be met with skepticism and suspicion, appears to have been supplemented with the far more optimistic possibility that individuals construct 'truths' of their own in the face of neoliberal universality and that these relative micro-conceptions of the world provide a refuge for 'free thought', dissent and political expression to the extent that all sociology needs to do is document them. 
At its extreme, groups of academics dedicated their careers to rooting out hidden subversive meanings in pop lyrics with Madonna's career a popular choice (see, for example, Schwichtenberg, 1993; Robertson, 1996) or analyzing the cultural subtexts of American teen dramas such as Dawson's Creek or Buffy the Vampire Slayer, the latter spawning 'buffyology' within the academy (see Badman, 2002 for an extensive list of academic work on the subject). More generally, clothing styles, music genres, shopping habits and film were all analyzed for sub rosa political implications (see Philo \& Miller, 2001 for a useful summary) as we cast around looking for signs of life in the barren wastelands of neoliberal universality.

At this point it is probably worth reiterating that this is not the only trend in evidence in sociological theory. Many alternate strands are immediately apparent with only the most cursory glance at the literature available to cultural sociologists. For every vaguely hagiographic text on the political meanings of various consumer proclivities there is another portraying the same activities as anxious, defensive reactions to an increasingly insecure culture. For every work seemingly convinced that we live in an increasingly free and prosperous society there is another arguing the same conditions to be signs of yet greater alienation and exploitation. In fact, 'The critique of alienation and spectacle has blossomed and spread to the point it has become the most common vulgate because it is the only discourse of consolation that we have' (Baudrillard, 2010: 41).

Nevertheless, to the extent that 'the cultural turn' and the implications of cultural relativism still form one of the main currents of sociological theory, we might note that it seems to be the product of a radical intelligentsia lacking an object capable of validating their commitment to a better, more egalitarian world. The outcome, however, seems to have been to:

unambiguously reformulate the relationship between social science and social critique: the social sciences were no longer expected to perform a critical function; they expelled critique beyond their own boundaries, turning it into nothing but a subject of study. The task from now on would be to study the critical potential of intersubjective communication... or the different regimes of justification and critique used by actors in their everyday practices. In this way the social sciences followed the spirit of the times: in a spirit of universal democratization and liberalization, they gave up their critical privileges and delegated them to citizens themselves (Znepolski, 2010: 2-3)

In other words, the direction taken by parts of the intellectual left after the cultural turn might seem to have delegated many of our critical responsibilities to individuals just going about their day-to-day lives. More than that, however, there remains a possibility that the tendency to focus our energies on elucidating individual experiences draws much of its inspiration from the universalizing spirit of capitalism that took hold during the nineteen-eighties. Obvious public success, apparent superiority to other socio-political discourses and emergent universal status seem to have dealt a blow to the interests of the radical intelligentsia that left us scrambling to find alternative ways to express dissent. However, instead of revitalizing intellectualism's critical inclinations for an era of totalitarian liberalism, we seemed to set about studying the forms of critique 
built into the everyday activities of ordinary people. This is an approach that might appear to have a great deal in common with Terry Eagleton's (1996) 'gloomy presupposition'.

What the recent history of our discipline perhaps indicates is that we may have fallen foul of the same problems that have plagued almost every quarter of the intellectual left for the last few decades. Rather than oppose neoliberalism on its own terms, perhaps with an equally compelling universality of our own, we seem to have retreated down the rabbit hole of individual critical potential, delegating some of our intellectual responsibilities to everyday citizens, most of whom are preoccupied with just trying to get by in an increasingly inhospitable world.

Insofar as too many on the academic and typing left have celebrated isolation as freedom and consumption as creativity, we have failed to counter the neoliberalisation of the economy. Even worse - we have failed to provide good reasons to support collective approaches to political, social and economic problems... We gave in, gave up, before we needed to. We actually didn't lose. It's worse than that. We quit [Original emphasis] (Dean, 2009: 4-5)

Ultimately, we may be looking at a causal relationship between the emergence of neoliberal universality and the subsequent character of much sociological theory. Faced with an apparently incontestable, unassailably popular socio-historical narrative it seems as though academic sociology was all but forced to abandon its relationship with radical social ideals and the possibility of building a better world through mass political mobilization. In a world that apparently believed it had solved all the biggest philosophical questions of human existence, sociology seems to have adopted a new political disposition that re-forged the discipline in line with the conditions of emergent universality. In other words, late-twentieth century sociology's renewed focus on the individual over and above macro-level social analysis allowed it to live on in a world system that apparently believed there was nothing to be gained in challenging the currently dominant 'master pattern'. However, in promulgating ideas such as identity politics, in getting involved with 'subcultures' - by definition marginally different cultural forms existing within an over-riding narrative - sociology appears to have accepted neoliberalism as a fait accompli and moved the discipline away from its roots in strident social critique.

Instead of meeting neoliberal universality head on and challenging it with alternative ideals, sociology set about relativizing universality, trying to show how it did not necessarily entail homogeneity, that even within conditions of ideological monism we might still find groups that differ, often in very marginal, unimportant and distinctly uninteresting ways, from dominant social ideals. In other words, going to great lengths to show that universality remains relative only to those who subscribe to its belief system and that critique can dynamically emerge from within such a monopolar political form. The problem we face is that as neoliberal universality has become increasingly troublesome, sociology appears to have moved away from the possibility of solving said problems through the mutability of macro-processes and structures leaving us struggling to participate in the growing debate around the future direction of our society in 
the wake of the financial crisis. Sociology, we might suggest, has transformed itself into a deeply unthreatening, vaguely liberal enterprise with little to contribute when it comes to the apparent decay of the liberal order.

\section{Conclusion (What is to be done?)}

This paper set out to explore a putative relationship between the emergent philosophical concept of neoliberal universalism and recent directions taken by social theory. The last decades of the twentieth century saw the emergence of a remarkable consensus around the social, political and economic legitimacy of neoliberalism. Slowly but surely the fundamental ideological oppositions that typified the middle decades of the twentieth century (see Hobsbawm, 1995; Badiou, 2007) fell away, replaced by a political monad that seemingly believed we had found a final solution to the great ethical problems of human history. It seemed that longstanding questions such as how we should live and what makes a 'good' society had been answered by the return of the free market and neoliberalism's ascent to political dominance. Now the business of politics lay only in neoliberalism's preservation. Any attempt to radically improve our social conditions, was believed to be the product of hopeless romanticism and perhaps even a dangerous risk likely to open the door for despotic government.

What's more, this determination has arguably produced a number of stagnant societies in which a host of worsening social problems - not least of which is the financial crises of the last few years - never seem to effect change in any of the underlying coordinates of our social existence, such as unfettered markets and 'free trade'. In this way we might be reminded of Boltanski and Chiapello's (2005) description of a society in which a booming, profoundly restructured capitalism breezily co-exists with social deterioration and rampant inequality whilst facing little in the way of real political opposition. Neoliberalism has, despite its many problems, become the single viable socio-historical narrative that explains how human society as a whole could and should work. It is, by all accounts, a universality that has become 'the only game in town'.

In this context we enquire after traditional sources of competing narratives, particularly sociological intellectuals and their longstanding affinity for political critique. What we perhaps find, however, is a discipline that appears to have delegated many of its critical responsibilities in a spirit of universal liberalization, expelling (political) critique outward to citizens themselves then setting about documenting their individual responses to an increasingly inhospitable society. Instead of devoting critical attention to neoliberal universality large sections of leftist sociology, particularly cultural sociology, have discovered an infinite source of diversity, multiplicity and agency in which individuals have gained the means and scope to transform their lives in fluid and dynamic ways while not challenging the basic co-ordinates of our social existence. This failure to meet neoliberalism head on arguably amounts to an intellectual retreat that opened the door for the re-adoption of classical liberalism on the socio-economic stage. 
What's more, the rise of neo-capitalist universality and the allied process of intellectual retreat are, perhaps, the final sum of the Chancellor's harried flight home and the mass bailout of the financial sector hurriedly finalized on his return. That we found ourselves in a situation where the only viable course of action barring wholesale economic collapse was to transfer billions of pounds of public money into private coffers for the express purpose of keeping our economy afloat must be indicative of a deeply imbalanced society. That the bailout attracted broad public support from the general population (Žižek, 2010) or that little progress has since been made in legislating away the worst excesses of financial markets further indicates the deep-seated malaise that seems to have overtaken traditional political bipolarity.

Once again, we are faced with the conclusion that neoliberalism 'occupies the horizon of the thinkable' (Fisher, 2009: 8) to such an extent that we couldn't see anything out the other side but the abject misery of complete socio-economic shutdown. In this vein, perhaps sociology, instead of doggedly pursuing individual critical potential, could take a role for itself amongst those trying to shed some light on the system we are in now and what we might find out the other side. Jean Baechler (2007) has noted that sociology has always been closer in its approach to disciplines such as philosophy and history than the natural sciences, in which case we might take a lead from those trying to turn critical philosophy to meeting our circumstances head on. Alain Badiou, for instance, recently proposed a triumvirate function for his discipline that would allow it to 'think the transformation of life':

First, to throw light on the fundamental choices of thought. 'In the last instance'... such choices are always between what is interested and what is disinterested.

Second, to throw light on the distance between thinking and power, between truths and the state. To measure this distance. To know whether or not it can be crossed.

Third, to throw light on the value of exception. The value of the event. The value of the break. And to do this against the continuity of life, against social conservatism (2009: 12).

While not wanting to step on his toes, there is no discernible reason why sociologists could not put more effort into highlighting the distance between any conception of an ethical society and its current form, then set about illustrating just how valuable a radical break could be. 


\section{References:}

Arrighi, G (2010) The Long Twentieth Century: Money, Power and the Origins of our Times (Updated Edition) London: Verso

Badiou, A (2010) The Communist Hypothesis (Trans. David Macey \& Steve Corcoran) London: Verso

Badiou, A (2009) 'Thinking the Event' in Peter Engelmann (Ed) Philosophy in the Present (Trans. Peter Thomas and Alberto Toscano) Cambridge: Polity

Badiou, A (2007) The Century (Trans. Alberto Toscano) Cambridge: Polity

Badman, D A (2002) ‘Academic Buffy Bibliography’ Available at: http://slayageonline.com/essays/slayage7/Badman.htm (Accessed: 31 March 2009)

Baechler, J (2007) 'But What Is Sociology?' European Journal of Social Theory 10 (2) pp 200-205

Bakan, J (2005) The Corporation: The Pathological Pursuit of Profit and Power London: Constable and Robinson

Baudrillard, J (2010) The Agony of Power (Trans. Ames Hodges) Los Angeles, CA: Semiotext(e)

Bauman, Z (1987) Legislators and Interpreters: On Modernity, Postmodernity and Intellectuals Cambridge: Polity Press

BBC News (2008) 'UK Banks Receive £37bn Bailout' Available at: http://news.bbc.co.uk/1/hi/business/7666570.stm (Accessed: 10 July 2011)

Boltanski, L \& Ève Chiapello (2005) The New Spirit of Capitalism (Trans. Gregory Elliott) London: Verso

Boudon, R (2004) The Poverty of Relativism (Trans. Peter Hamilton) Oxford: The Bardwell Press

Bourdieu, P (1988) Homo Academicus Cambridge: Polity Press

Callinicos, A (2010) Bonfire of Illusions: Twin Crises of the Liberal World Cambridge: Polity Press

Chang, H-J (2010) 23 Things They Don't Tell You About Capitalism London: Allen Lane

Chomsky, N (2004) Hegemony or Survival: America's Quest for Global Dominance London: Penguin Books

Cohen, N (2007) What's Left?: How the Left Lost its Way London: Harper Perennial

Dean, J (2009) Democracy and Other Neoliberal Fantasies Durham: Duke University Press

Deutschmann, C (2001) 'The Promise of Absolute Wealth: Capitalism as Religion' Thesis Eleven 66 pp 32-56

Dorling, D (2010) Injustice: Why Social Inequality Persists Bristol: The Policy Press

Dyer, G (2010) Climate Wars: The Fight for Survival as the World Overheats Oxford: Oneworld

Eagleton, T (1996) The Illusions of Postmodernism Oxford: Blackwell Publishers

Elliott, L \& Dan Atkinson (2007) Fantasy Island: Waking up to the Incredible Economic, Social and Political Illusions of the Blair Legacy London: Constable

Elliott, L \& Dan Atkinson (1998) The Age of Insecurity London: Verso

Ferguson, N (2008) The Ascent of Money: A Financial History of the World London: Allen Lane 
Fisher, M (2009) Capitalist Realism: Is There No Alternative? Winchester: Zero Books

Freeman, D \& Jason Freeman (2008) Paranoia: The Twenty-First Century Fear Oxford: Oxford University Press

Frieden, J A (2006) Global Capitalism: Its fall and Rise in the Twentieth Century London: W. W. Norton \& Company

Fukuyama, F (1992) The End of History and the Last Man London: Penguin

Furedi, F (2004) Where Have all the Intellectuals Gone?: Confronting $21^{\text {st }}$ Century Philistinism London: Continuum

Galbraith, J K (1994) The World Economy Since the Wars: A Personal View London: Sinclair-Stephenson

Giddens, A (1991) Modernity and Self-Identity Cambridge: Polity Press

Gray, J (2007) Black Mass: Apocalyptic Religion and the Death of Utopia London: Penguin

Gray, J (2002) False Dawn: The Delusions of Global Capitalism London: Granta

Hall, S. (2012) Theorizing Crime and Deviance: A New Perspective London: Sage

Hall, S, Winlow, S \& Ancrum, C (2008) Criminal Identities and Consumer Culture: Crime, Exclusion and the New Culture of Narcissism Cullompton: Willan

Harvey, D (2010) The Enigma of Capital: and the Crises of Capitalism London: Profile Books

Harvey, D (2005) A Brief History of Neoliberalism Oxford: Oxford University Press

Hobsbawm, E J (2011) How to Change The World: Tales of Marx and Marxism London: Little, Brown

Hobsbawm, E J (1995) Age of Extremes: The Short Twentieth Century 1914-1991 London: Abacus

Hutton, W (2010) Them and Us: Changing Britain - Why We Need a Fairer Society London: Little, Brown

Johnson, C (2002) Blowback: The Costs and Consequences of American Empire London: Time Warner

Judt, T (2010) Ill Fares the Land: A Treatise on Our Present Discontents London: Allen Lane

Kindleberger, C (2000) Manias, Panics and Crashes: A History of Financial Crises New York, NY: Wiley

Kinzer, S (2003) All the Shah's Men: An American Coup and the Roots of Middle East Terror Hoboken, NJ: Wiley

Lane, R E (2000) The Loss of Happiness in Market Democracies London: Yale University Press

Langley, P (2009) The Everyday Life of Global Finance: Saving and Borrowing in Anglo-America Oxford: Oxford University Press

Losurdo, D (2011) Liberalism: A Counter History London: Verso

Lovelock, J (2009) The Vanishing Face of Gaia London: Allen Lane

Lukes, S (2008) Moral Relativism London: Profile Books

MacDonald, R (2009) 'Precarious Work: Risk, Choice and Poverty Traps', in Furlong, A (ed) Handbook of Youth and Young Adulthood: New Perspectives and Agendas Abingdon: Routledge pp 167-175.

Mackay, C (1852 [1995]) Extraordinary Popular Delusions and the Madness of Crowds Ware: Wordsworth Editions

Mills, C W (1959) The Sociological Imagination Oxford: Oxford University Press 
Mitchell, T (2007) 'Dreamland' in Mike Davis and Daniel Bertrand Monk (eds) Evil Paradises: Dreamworlds of Neoliberalism New York, NY: The New Press

Pettifor, A (2006) The Coming First World Debt Crisis London: Palgrave Macmillan Philo, G \& David Miller (2001) Market Killing: What the Free Market Does and What Social Scientists can do About It Harlow: Longman

Pilger, J (2007) The War on Democracy [Film] United Kingdom: Lions Gate

Rancière, J (2005) Hatred of Democracy London: Verso

Reinhart, C \& Kenneth Rogoff (2009) This Time Is Different: Eight Centuries of Financial Folly Oxford: Princeton University Press

Robertson, P (1996) Guilty Pleasures: Feminist Camp from Mae West to Madonna London: I B Tauris

Rojek, C \& Bryan Turner (2000) 'Decorative Sociology: Towards a Critique of the Cultural Turn' The Sociological Review 48 (4) pp629-648

Schumaker, J F (2006) In Search of Happiness: Understanding an Endangered State of Mind London: Praegar

Schumpeter, J A (1942 [2011]) Capitalism, Socialism and Democracy ( $2^{\text {nd }}$ Edn) Harper \& Brothers Publishers

Schwichtenberg, C (1993) The Madonna Connection: Representational Politics, Subcultural Identities and Cultural Theory Boulder, CO: Westview Press

Sorman, G (2009) Economics Does Not Lie: A Defense of the Free Market in a Time of Crisis London: Encounter Books

Southwood, I (2011) Non-Stop Inertia Winchester: Zero Books

Standing, G (2011) The Precariat: The New Dangerous Class London: Bloomsbury

Toynbee, P \& David Walker (2010) The Verdict: Did Labour Change Britain? London: Granta

Vince, G (2009) 'Surviving in a Warmer World' New Scientist No: 2697 (28 February)

Wallerstein, I (2011) 'The World System After 1945' Eurozine Available at: http://www.eurozine.com/pdf/2011-04-29-wallerstein-en.pdf (Accessed: 29 April 2011)

Williams, E C (2011) Combined and Uneven Apocalypse Winchester: Zero books

Wilkinson, R \& Kate Pickett (2009) The Spirit Level: Why More Equal Societies Almost Always Do Better London: Allen Lane

Wolf, M (2010) Fixing Global Finance: How to Curb Financial Crises in the $21^{\text {st }}$ Century (Expanded Edition) London: Yale University Press

Žižek, S (2010) Living in the End Times London: Verso

Žižek, S (2009) First As Tragedy, Then As Farce London: Verso

Žižek, S (2000) ‘Class Struggle or Postmodernism? Yes Please!' in Judith Butler, Ernesto Laclau \& Slavoj Žižek (eds) Contingency, Hegemony, Universality: Contemporary Dialogues on the Left London: Verso

Znepolski, B (2010) 'On the Strengths and Weaknesses of Academic Social Critique' Eurozine Available at: http://www.eurozine.com/pdf/2010-11-26znepolski-en.pdf (Accessed: 9/5/11) 